\title{
The Effectiveness of Aromatherapy in the Management of Labor Pain and Anxiety: A Systematic Review
}

\author{
Mahbubeh Tabatabaeichehr ${ }^{1}$, Hamed Mortazavi ${ }^{2 *}$
}

\footnotetext{
OPEN ACCESS

Citation: Mahbubeh Tabatabaeichehr, Hamed Mortazavi. The Effectiveness of Aromatherapy in the Management of Labor Pain and Anxiety: A Systematic Review. Ethiop J Health Sci. 2020;30(3):449.doi:http://dx.doi.org/10.431 4/ejhs.v30 i3.16

Received: January 3, 2020

Accepted: January 30, 2020

Published: May 1, 2020

Copyright: (C2020 Muhbubeh T., et al. This is an open access article distributed under the terms of the Creative Commons Attribution License, which permits unrestricted use, distribution, and reproduction in any medium, provided the original author and source are credited. Funding: Nil

Competing Interests: The authors declare that this manuscript was approved by all authors in its form and that no competing interest exists.

Affiliation and Correspondence:

${ }^{1}$ Geriatric Care Research Center, Department of Midwifery, School of Nursing and Midwifery, North Khorasan University of Medical Sciences, Bojnurd, Iran

${ }^{2}$ Geriatric Care Research Center, Department of Geriatric Nursing, School of Nursing and Midwifery, North Khorasan University of Medical Sciences, Bojnurd, Iran *Email:

hamedmortazavi@ymail.com
}

ABSTRACT
BACKGROUND: Aromatherapy as an alternative and complementary medicine is a well-known method for reducing the symptoms of various physiological processes such as labor experience. The aim of this study was to systematically review the currently available evidences evaluating the use of aromatherapy for management of labor pain and anxiety.

METHODS: In a systematic review, 5 databases (PubMed, SCOPUS, Web of Science, Google Scholar and Scientific Information Database [SID]) were searched, from database inception up to December 2019. Keywords used included (aromatherapy OR " "essential oil" OR "aroma") AND (pain OR anxiety) AND (labor OR delivery). Using the Cochrane Collaboration's 'Risk of bias' method; the risk of bias in the included studies was evaluated.

RESULTS: A total of 33 studies were verified to meet our inclusion criteria. Most of the included studies were conducted in Iran. Aromatherapy was applied using inhalation, massage, footbath, birthing pool, acupressure, and compress. The most popularly used essential oil in the studies was lavender (13 studies), either as a single essential oil or in a combination with other essential oils. Most of included studies confirmed the positive effect of aromatherapy in reducing labor pain and anxiety.

CONCLUSION: The evidences from this study suggest that aromatherapy, as a complementary and alternative modality, can help in relieving maternal anxiety and pain during labor.

KEYWORDS: Aromatherapy; Labor Pain, Anxiety; Systematic Review

\section{INTRODUCTION}

Pain is an unavoidable reality of labor and the most noticeable determinant of the labor experience. The perception of pain during labor is due to cervical dilation, contractions of the uterus and the uterine extension for vaginal delivery (1). Inadequate labor pain management can be associated with negative physiological and psychological consequences. Additionally, it has been previously indicated that there is an association between labor anxiety and 
pain (2). Anxiety stimulates the sympathetic nervous system and releases stress related hormones such as noradrenaline, cortisol and adrenaline, which consequently increase the severity of labor pain as well as the duration of labor (3). Therefore, finding a way to provide a maximum pain relief feeling and calmness, with the minimum complications, is one of the most important issues during labor (4-5). Pharmacological and non-pharmacological approaches are two general methods that currently used to alleviate labor pain and anxiety. Nowadays, non-pharmacological approaches such as relaxation techniques, acupuncture, acupressure, massage therapy and aromatherapy have been identified a prominent area in midwifery science due to their price-effectiveness, popularity, simplicity of use and low risks $(1,4)$.

Aromatherapy, as a non-pharmacologic and complementary and alternative therapy, is the application of essential oils from natural crops to relax and control the mind and body through aromatic compounds and essential oils with the neurological and physiological effects (6). Using aromatherapy in the care of women has a long history (7). Among pregnant women, complementary and alternative therapies are common approaches. Evidence from different countries indicates rates of use of aromatherapy in pregnant women increasing from $13 \%$ to $78 \%$ (8). Also, use of aromatherapy is suggested during labor, with no significant reported side effects in the mothers and neonates (9).

Although aromatherapy is widely used among pregnant women and several studies have been conducted to evaluate its anxiolytic and pain reducing effect during labor, to our knowledge, there is no comprehensive systematic review to evaluate the efficacy of aromatherapy in reducing labor pain and anxiety. Therefore, the aim of this study was to comprehensively and critically evaluate the available evidence regarding the effectiveness of aromatherapy in the management of labor pain and anxiety.

\section{METHODS}

In a systematic review, 5 databases (PubMed, SCOPUS, Web of Science, Google Scholar and Scientific Information Database [SID]) were searched, from database inception up to December 2019. Keywords used included (aromatherapy OR "essential oil" OR aroma*) AND (pain OR anxiety) AND (labor OR delivery). The languages of the studies were restricted to the Persian and English. For searching in Persian electronic databases, keywords equivalents in Farsi were used. The references list of included studies have been manually checked to ensure that relevant studies have not been skipped. Criteria for inclusion of studies were full-length, peer-reviewed clinical trial studies which evaluated the effects of aromatherapy on labor pain and anxiety. Studies with high risk of bias or those studies in which the effects of aromatherapy during labor was not the primary outcome of interest were excluded.

Study selection: The search records were imported into Endnote software, and duplicates were deleted. Potentially relevant papers were subsequently retrieved, and their full texts were read to decide if they met the above mentioned inclusion criteria. Two independent reviewers carried out these procedures. Disagreements were resolved by discussion.

Data extraction and quality assessment: Two independent reviewers carried out data collection using a predetermined checklist, and subsequently, the third reviewer checked the results of the process. Information such as country, authors' name, year of publication, participants and study characteristics, aromatherapy intervention and outcomes were extracted from the included studies. Risk of bias (reporting, selection, performance, detection and attrition bias) in the included studies were evaluated using the "risk of bias" method of the Cochrane Collaboration (10). Each of them were categorized as "high risk," "low risk," or "unclear risk" of bias. Disagreements were resolved by discussion.

\section{RESULTS}

At the initial investigation, 1874 papers were obtained. Fifty-two articles remained for further full text analysis after removing 396 duplicates and 1426 irrelevant papers. At this step, a total of 19 studies were excluded. Finally, 33 studies were been verified to meet our criteria for inclusion (1143) (Figure 1). 

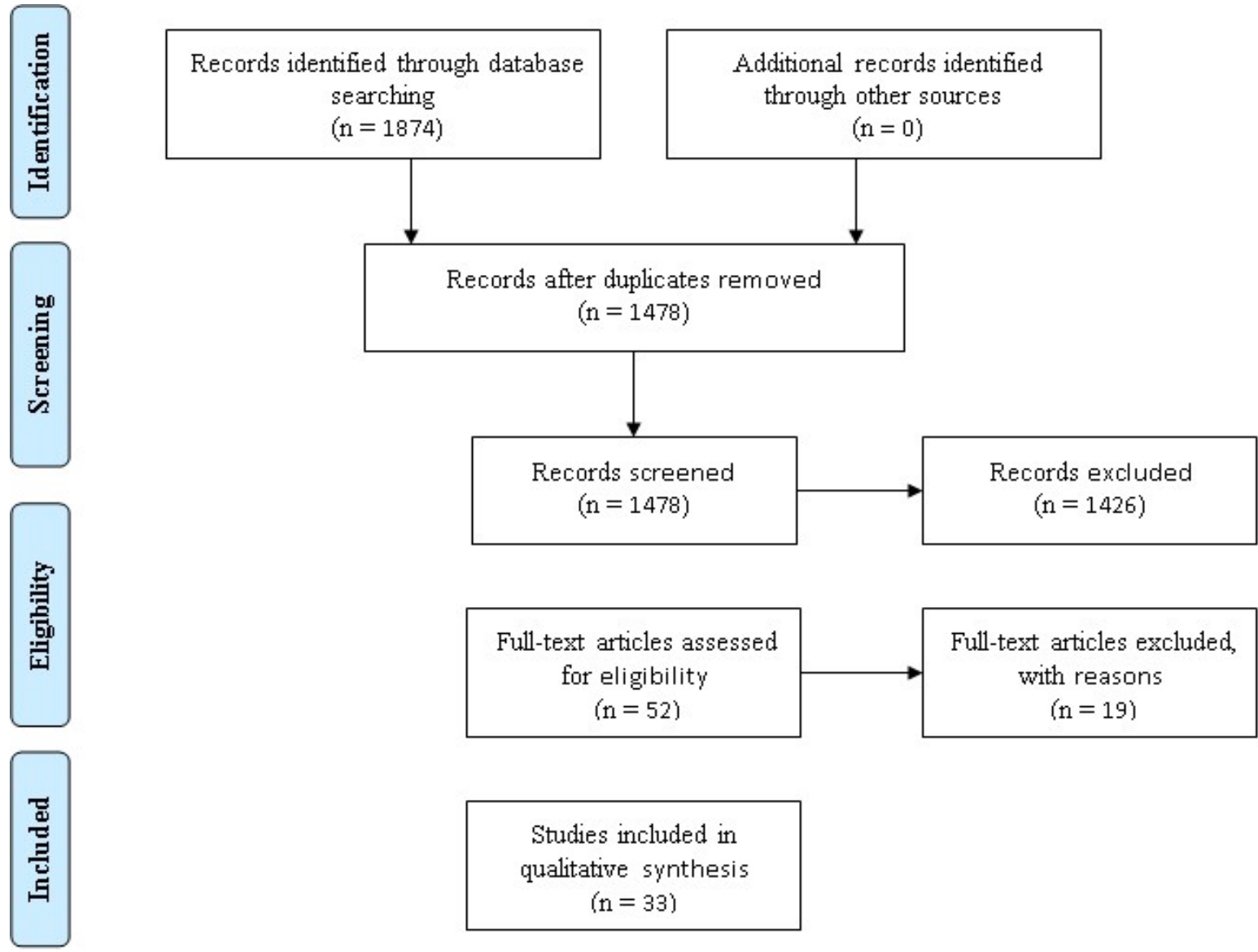

Studies included in qualitative synthesis $(\mathrm{n}=33)$

Figure 1: Literature search flow diagram

Study selection and characteristics: All the selected studies were published between 2003 and 2018. Twenty seven of the included studies were carried out in Iran, 2 study in Korea, 1 study in Egypt, 1 study in Italy and 2 studies in India. All 33 studies were planned in parallel group design.

Participants: Number of individual study participants varied from 48 to 600 . Thirty studies included primiparous women while 3 researches were not limited by parity.

Interventions: Inhalation (12,14,19-24,26-30,3336,38-42), massage (11-13,17-18,25,31,37) footbath $(12,21)$, inhalation and footbath, birthing pool, points for acupressure and compress (12), were the forms of aromatherapy administration in the included studies. The most essential oil used in the studies was lavender (13 studies).

Risk of bias evaluation: In 15 trials, random sequence generation was accurately described. The other studies did not describe the process of sequence generation. Description about allocation concealment was sufficient in 7 studies $(12,17,19$ $20,28,36,40)$. In 8 of the studies included, there was a high risk for participant blindness $(9,14,16,18,33-35,40)$. All the studies were found to have a low risk of bias for incomplete outcome data and selective reporting (Figure 2; Figure 3). 


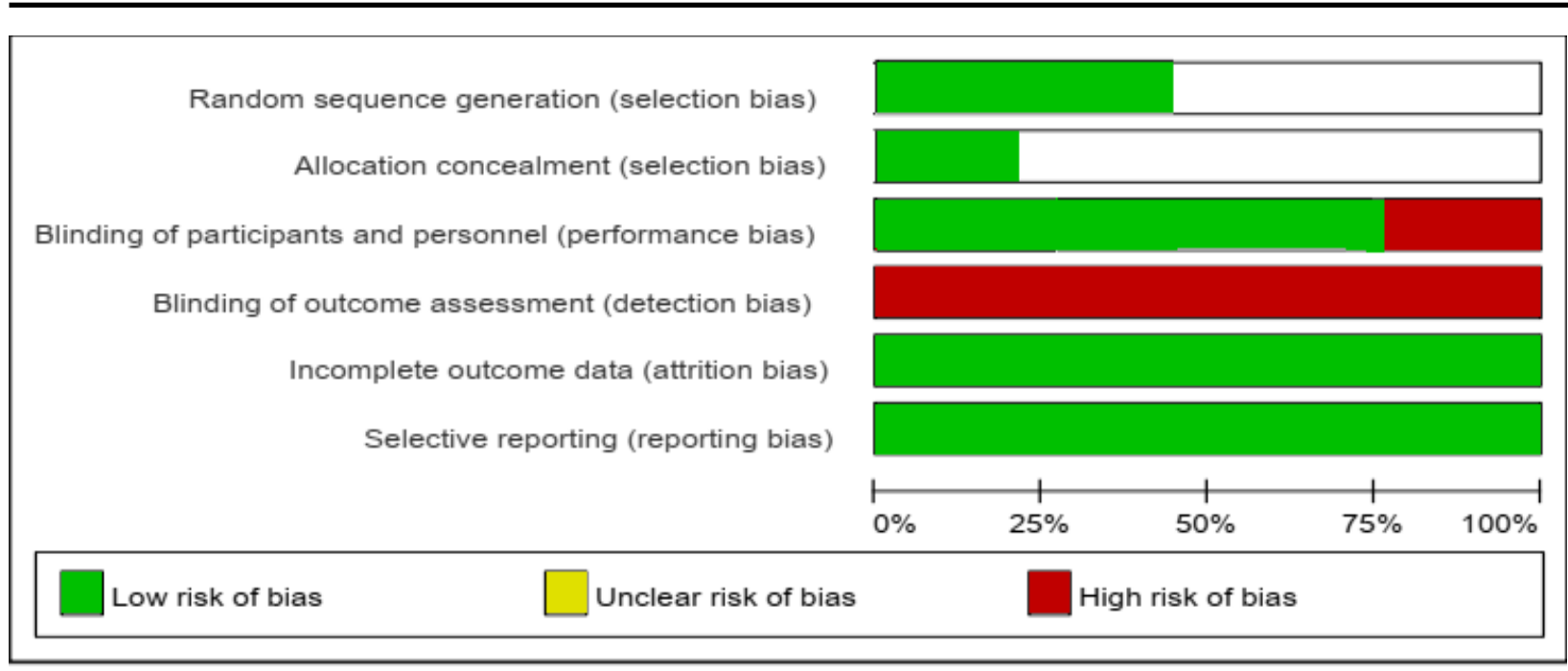

Figure 2: Risk of bias in all the evaluated studies

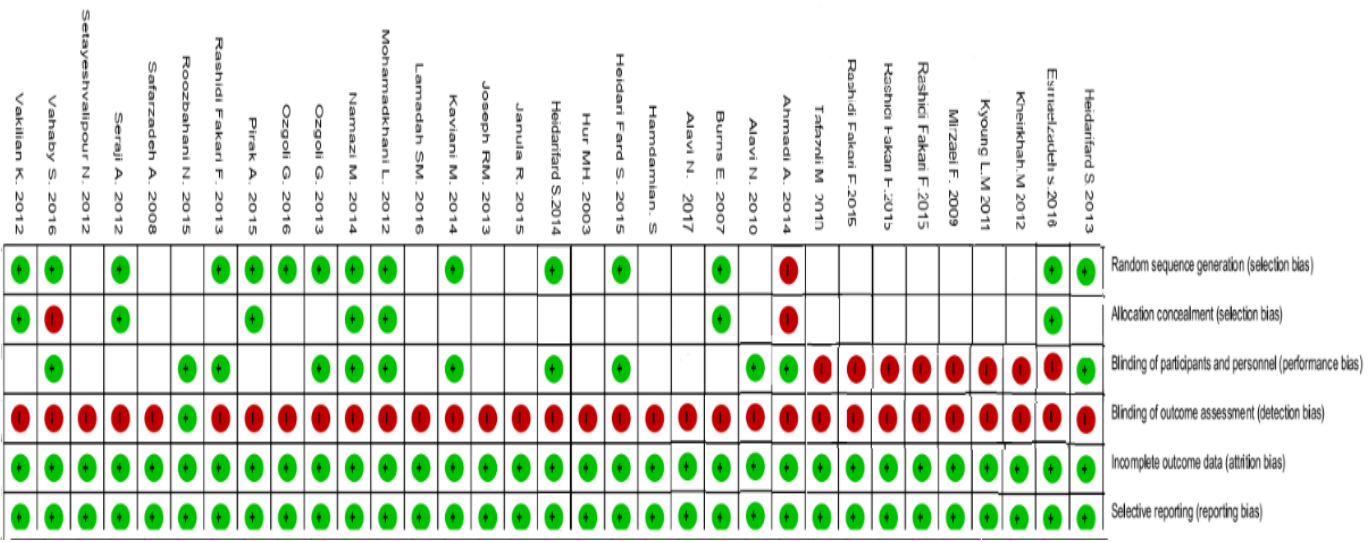

Figure 3: Risk of bias summery in all the evaluated studies

The effects of Lavender aromatherapy on labor pain and anxiety: Lavender (Lavandula spp) is one of the most commonly used plant species in aromatherapy (44). Vakiliain et al. and Ahmadi et al. showed that inhalation of lavender essential oil significantly decreased pain intensity during labor $(20,23)$. Yazdkhasti et al. also indicated that aromatherapy with lavender essential oil significantly decreased pain intensity during labor (36). Alavi et al. showed that labor-induced pain intensity in the lavender inhalation group significantly decreased in 30 and 60 minutes after the intervention (15). Mohammadkhani et al. indicate that aromatherapy massage with lavender essential oil significantly reduced the pain score in the active phase of labor (17). Seraji et al. found that the lavender aromatherapy was more significantly efficient than reathing techniques in reducing labor pain intensity (19). Janula et al. showed that both lavender massage aromatherapy and biofeedback therapy could decrease the pain level during labor; however, the effect of lavender aromatherapy was greater than biofeedback therapy (31). Another study showed that lavender aromatherapy massage significantly reduced the pain intensity in the aromatherapy group compared to the aromatherapy-free massage as the control group (37). A study by Safarzadeh et al. indicated that during labor, massage with essential oil of lavender significantly reduced the pain severity as compared to routine labor cares (13).

DOI: http://dx.doi.org/10.4314/ejhs.v30i3.16 
Using lavender by massage, inhalation, acupressure, tapering, compression, footbath, or birthing pool in order to minimize of anxiety levels during labor have been evaluated in multiple studies $(12,14,16,18,37)$. Burns et al. indicate that aromatherapy (commonly with lavender essential oil) can significantly reduce anxiety during the first phase of labor (12). Mirzaei et al. and Tafazoli et al. demonstrated that the anxiety level in the lavender inhalation group significantly reduced in 60 minutes after lavender inhalation $(14,16)$. Tafazoli et al also indicated that inhalation of lavender in the intervention group instantly reduced the level of anxiety (16).

The effects of Rosa aromatherapy on labor pain and anxiety: Rosa damascene or Damascus rose is one of the species in the Rosacea family in certain parts of Europe and the Middle East (45-46). Vahaby et al. indicated that the mean labor pain intensity in the Rosa water aromatherapy group decreased significantly only at $8-10 \mathrm{~cm}$ of cervical dilation (24\%) compared with the control group (38). Another study confirmed the efficacy of Rosa aromatherapy in reducing labor pain (39). Setayeshvalipur et al. showed that Rosa essential oil inhalation and footbath aromatherapy with Rosa essential oil are more effective in decreasing pain level compared to the warm-water footbath during labor (21). Two studies confirmed the efficacy of inhalation aromatherapy with Rosa essential oil in reducing pain intensity $(13,27)$. Nehbandani et al. showed that aromatherapy with lavender essential oil, compared to rose essential oil, resulted in a more significant reduction in labor pain (43). Kheirkhah et al. indicate that both footbath aromatherapy and inhalation aromatherapy with essential oil of rose are effective in reducing labor anxiety (22). Also, Hamdamian et al. indicate the effectiveness of Rosa inhalation aromatherapy in reducing labor anxiety (27). Other studies do not support the efficacy of Rosa aromatherapy in reducing labor anxiety (11).

The effects of Jasmin aromatherapy on labor pain and anxiety: Jasmin, known as the Jasmine officinale, is a species belonging to Oleaceae family (47-48). Joseph et al. showed that aromatherapy massage with Jasmin extract significantly decreased pain severity in the first stage of labor compared with the control group (25). Other studies do not support the effectiveness of inhalation aromatherapy with jasmine extract in reducing labor pain (30). Alavi et al. indicate that the massage with jasmine oil is more effective in relieving pain during labor than the jasmine oil aromatherapy (42).

The effects of Geranium aromatherapy on labor pain and anxiety: Geranium (Pelargonium graveolens) is a member of the Geraniaceae family (49). Safarzade et al. showed that massage with essential oil of geranium compared to the routine labor cares significantly reduced the pain intensity during labor (13). Another study showed that aromatherapy with geranium essential oil, compared with orange peel essential oil, does not have significant efficacy in reducing labor pain (24). Rashidi-Fakari et al. confirmed the antianxiolytic effects of the inhalation of geranium essential oil in reducing labor anxiety (33). Another study by Rashidi-Fakari and Tabatabaeichehr compared the anti-anxiety impact of essential oil of geranium with essential oil of orange peel during the first step of labor. In this study, anxiety levels for geranium and orange peel groups decreased 20 minutes after the interventions. Interestingly, there was a greater decrease in the geranium group than in the orange peel group (34).

The effects of Chamomile aromatherapy on labor pain and anxiety: Chamomile is a half yearly member of the Asteraceae family (50). Heidarifard et al. showed the efficacy of chamomile aromatherapy in reducing labor pain and anxiety $(29,32)$. Burns et al. showed the efficacy of chamomile essential oil aromatherapy in decreasing the pain intensity and the anxiety level in nulliparous women during the first stage of labor (12).

The effects of Peppermint aromatherapy on labor pain and anxiety: Peppermint (Mentha piperita) is a member of the Lamiaceae family (51). Ozgoli et al. in two separated studies confirmed the efficacy of peppermint aromatherapy in reducing labor pain and anxiety $(26,41)$.

DOI: http://dx.doi.org/10.4314/ejhs.v30i3.16 
Table 1: Basic features of included studies

\begin{tabular}{|c|c|c|c|c|c|c|}
\hline Author/Year & Country & $\begin{array}{l}\text { Number of } \\
\text { Participants }\end{array}$ & Intervention & Assessment & $\begin{array}{l}\text { Efficacy of } \\
\text { aromatherapy }\end{array}$ & Parity \\
\hline Hur and Park. 2003. (11) & Korea & 48 & Aromatherapy massage & $\begin{array}{l}\text { Pain and anxiety ( } 120 \text { minutes after } \\
\text { intervention) }\end{array}$ & Not significant & Primipara \\
\hline Burns et al. 2007. (12) & Italy & 513 & $\begin{array}{l}\text { Inhalation } \\
\text { aromatherapy }\end{array}$ & Anxiety and pain (after intervention) & $\begin{array}{l}\text { Significant for } \\
\text { both }\end{array}$ & $\begin{array}{l}\text { Primipara/ } \\
\text { Multipara }\end{array}$ \\
\hline Safarzadeh et al. 2008. (13) & Iran & 60 & Aromatherapy massage & Pain (after intervention) & Significant & Primipara \\
\hline Mirzaei F et al. 2009. (14) & Iran & 121 & $\begin{array}{l}\text { Inhalation } \\
\text { aromatherapy }\end{array}$ & Anxiety (60 min after the intervention) & $\begin{array}{l}\text { Significant: } 60 \\
\text { minutes after the } \\
\text { intervention }\end{array}$ & Primipara \\
\hline Alavi et al. 2010. (15) & Iran & 160 & $\begin{array}{l}\text { Inhalation } \\
\text { aromatherapy }\end{array}$ & $\begin{array}{l}\text { Pain ( } 30 \text { and } 60 \text { minutes after the } \\
\text { intervention) }\end{array}$ & Significant & Primipara \\
\hline Tafazoli M et al. 2010. (16) & Iran & 102 & $\begin{array}{l}\text { Inhalation } \\
\text { aromatherapy }\end{array}$ & $\begin{array}{l}\text { Anxiety (immediately and } 60 \\
\text { minutes after intervention) }\end{array}$ & $\begin{array}{l}\text { Significant: } 60 \\
\text { min after the } \\
\text { intervention }\end{array}$ & Primipara \\
\hline $\begin{array}{l}\text { Mohammad khani et al. } \\
\text { 2011.(17) }\end{array}$ & Iran & 90 & Aromatherapy massage & $\begin{array}{l}\text { Pain ( } 30 \text { minutes after the } \\
\text { intervention) }\end{array}$ & Significant & Primipara \\
\hline $\begin{array}{l}\text { Kyoung and Haeng. } 2011 . \\
\text { (18) }\end{array}$ & Korea & 81 & Aromatherapy massage & $\begin{array}{l}\text { Anxiety (latent phase and after the } \\
\text { intervention) }\end{array}$ & Significant & $\begin{array}{l}\text { Primipara/ } \\
\text { Multipara } \\
\end{array}$ \\
\hline Seraji et al. 2011. (19) & Iran & 120 & $\begin{array}{l}\text { Inhalation } \\
\text { aromatherapy }\end{array}$ & $\begin{array}{l}\text { Pain (after the intervention at active } \\
\text { phase of labor). }\end{array}$ & Significant & Multipara \\
\hline Vakilian et al. 2012. (20) & Iran & 120 & $\begin{array}{l}\text { Inhalation } \\
\text { aromatherapy }\end{array}$ & $\begin{array}{l}\text { Pain (three times after the } \\
\text { intervention). }\end{array}$ & Significant & Multipara \\
\hline $\begin{array}{l}\text { Setayeshvalipur et al. } 2012 . \\
\text { (21) }\end{array}$ & Iran & 120 & $\begin{array}{l}\text { Inhalation \& Footbath } \\
\text { aromatherapy }\end{array}$ & Pain (30 minutes after intervention) & Significant & Primipara \\
\hline $\begin{array}{l}\text { Kheirkhah M et al. } 2012 . \\
\text { (22) }\end{array}$ & Iran & 120 & $\begin{array}{l}\text { Inhalation \& Footbath } \\
\text { aromatherapy }\end{array}$ & Anxiety (after intervention) & Significant & Primipara \\
\hline Ahmadi et al. 2013. (23) & Iran & 70 & $\begin{array}{l}\text { Inhalation } \\
\text { aromatherapy }\end{array}$ & $\begin{array}{l}\text { Pain (after the } \\
\text { intervention for } 1 \text { hour) }\end{array}$ & Significant & Primipara \\
\hline $\begin{array}{l}\text { Rashidi Fakari et al. } 2013 . \\
\text { (24) }\end{array}$ & Iran & 130 & $\begin{array}{l}\text { Inhalation } \\
\text { aromatherapy }\end{array}$ & $\begin{array}{l}\text { Pain (after intervention at active phase } \\
\text { of labor). }\end{array}$ & Significant & Primipara \\
\hline Joseph et al. 2013. (25) & India & 130 & Massage aromatherapy & $\begin{array}{l}\text { Pain ( } 30 \text { and } 120 \text { minutes after } \\
\text { intervention) }\end{array}$ & Significant & Primipara \\
\hline Ozgoli et al. 2013. (26) & Iran & 128 & $\begin{array}{l}\text { Inhalation } \\
\text { aromatherapy }\end{array}$ & $\begin{array}{l}\text { Pain and anxiety (after intervention at } \\
\text { active phase of labor) }\end{array}$ & $\begin{array}{l}\text { Significant for } \\
\text { both }\end{array}$ & Primipara \\
\hline $\begin{array}{l}\text { Hamdamian et al. } 2014 . \\
\text { (27) }\end{array}$ & Iran & 110 & $\begin{array}{l}\text { Inhalation } \\
\text { aromatherapy }\end{array}$ & $\begin{array}{l}\text { Pain and anxiety (after intervention at } \\
\text { active phase of labor) }\end{array}$ & $\begin{array}{l}\text { Significant for } \\
\text { both }\end{array}$ & Primipara \\
\hline Namazi et al. 2014. (28) & Iran & 126 & $\begin{array}{l}\text { Inhalation } \\
\text { aromatherapy }\end{array}$ & $\begin{array}{l}\text { Pain and anxiety (after intervention at } \\
\text { active phase of labor) }\end{array}$ & $\begin{array}{l}\text { Significant for } \\
\text { both }\end{array}$ & Primipara \\
\hline $\begin{array}{l}\text { Heidarifard et al. } 2014 . \\
\text { (29) }\end{array}$ & Iran & 130 & $\begin{array}{l}\text { Inhalation } \\
\text { aromatherapy }\end{array}$ & $\begin{array}{l}\text { Pain and anxiety (after intervention at } \\
\text { active phase of labor) }\end{array}$ & $\begin{array}{l}\text { Significant for } \\
\text { both }\end{array}$ & Primipara \\
\hline Kaviani et al. 2014. (30) & Iran & 156 & $\begin{array}{l}\text { Inhalation } \\
\text { aromatherapy }\end{array}$ & $\begin{array}{l}\text { Pain ( } 30 \text { and } 60 \text { minuets } \\
\text { after intervention) }\end{array}$ & Not significant & Primipara \\
\hline Janula et al. 2015. (31) & India & 600 & $\begin{array}{l}\text { Inhalation } \\
\text { aromatherapy }\end{array}$ & $\begin{array}{l}\text { Pain and anxiety (after intervention at } \\
\text { active phase of labor) }\end{array}$ & Significant & Primipara \\
\hline $\begin{array}{l}\text { Heidaryfard et al. } 2015 . \\
\text { (32) }\end{array}$ & Iran & 130 & $\begin{array}{l}\text { Inhalation } \\
\text { aromatherapy }\end{array}$ & $\begin{array}{l}\text { Pain (after intervention at active phase } \\
\text { of labor) }\end{array}$ & Significant & Primipara \\
\hline $\begin{array}{l}\text { Rashidi Fakari et al. } 2015 . \\
\text { (33) }\end{array}$ & Iran & 100 & $\begin{array}{l}\text { Inhalation } \\
\text { aromatherapy }\end{array}$ & Anxiety (20 min after the intervention) & Significant & Primipara \\
\hline $\begin{array}{l}\text { Fakari and } \\
\text { Tabatabaeichehr. } 2015 \text {. } \\
\text { (34) }\end{array}$ & Iran & 100 & $\begin{array}{l}\text { Inhalation } \\
\text { aromatherapy }\end{array}$ & $\begin{array}{l}\text { Anxiety ( } 20 \text { min after the } \\
\text { intervention) }\end{array}$ & Not significant & Primipara \\
\hline $\begin{array}{l}\text { Rashidi-Fakari et al. } 2015 . \\
\text { (35) }\end{array}$ & Iran & 100 & $\begin{array}{l}\text { Inhalation } \\
\text { aromatherapy }\end{array}$ & Anxiety (20 min after the intervention) & Not significant & Primipara \\
\hline Yazdkhasti et al. 2016. (36) & Iran & 120 & $\begin{array}{l}\text { Inhalation } \\
\text { aromatherapy }\end{array}$ & $\begin{array}{l}\text { Pain ( } 30 \text { minutes after the } \\
\text { intervention at active phase of labor) }\end{array}$ & Significant & Primipara \\
\hline $\begin{array}{l}\text { Lamadeh and Nomani. } \\
\text { 2016. (37) }\end{array}$ & Egypt & 600 & Massage aromatherapy & $\begin{array}{l}\text { Pain and anxiety (after the } \\
\text { intervention at active phase of labor) }\end{array}$ & $\begin{array}{l}\text { Significant for } \\
\text { both }\end{array}$ & Primipara \\
\hline Vahaby et al. 2016. (38) & Iran & 80 & $\begin{array}{l}\text { Inhalation } \\
\text { aromatherapy }\end{array}$ & $\begin{array}{l}\text { Pain (after the intervention at active } \\
\text { phase of labor) }\end{array}$ & Significant & Primipara \\
\hline $\begin{array}{l}\text { Roozbahani et al. } 2016 . \\
\text { (39) }\end{array}$ & Iran & 111 & Massage aromatherapy & $\begin{array}{l}\text { Pain ( } 30 \text { minutes after the } \\
\text { intervention) }\end{array}$ & Significant & Primipara \\
\hline $\begin{array}{l}\text { Esmaelzadeh et al. } 2016 . \\
\text { (40) }\end{array}$ & Iran & 126 & $\begin{array}{l}\text { Inhalation } \\
\text { aromatherapy }\end{array}$ & Anxiety (after the intervention) & Significant & Nullipara \\
\hline Ozgoli et al. 2016. (41) & Iran & 126 & $\begin{array}{l}\text { Inhalation } \\
\text { aromatherapy }\end{array}$ & $\begin{array}{l}\text { Pain and anxiety (after the } \\
\text { intervention at active phase of labor) }\end{array}$ & Significant & Primipara \\
\hline Alavi et al. 2017. (42) & Iran & 120 & $\begin{array}{l}\text { Inhalation \& Footbath } \\
\text { aromatherapy }\end{array}$ & Pain (after the intervention) & Significant & Primipara \\
\hline $\begin{array}{l}\text { Nehbandani et al. } 2018 . \\
\text { (43) }\end{array}$ & Iran & 160 & $\begin{array}{l}\text { Inhalation } \\
\text { aromatherapy }\end{array}$ & $\begin{array}{l}\text { Pain (after the intervention at active } \\
\text { phase of labor) }\end{array}$ & Significant & Primipara \\
\hline
\end{tabular}

DOI: http://dx.doi.org/10.4314/ejhs.v30i3.16 
The effects of Sweet orange aromatherapy on labor pain and anxiety: The sweet orange belongs to Rutaceae family (Citrus sinensis) (52). RashidiFakari et al. reported the significant efficacy of aromatherapy with essential peel oil of sweet orange on labor pain and anxiety $(24,35)$. However, another study by Rashidi-Fakari and Tabatabaeichehr does not support the superior efficacy of orange essential oil than geranium essential oil in reducing labor anxiety (34).

The effects of Bitter orange (Citrus aurantium) essential oil aromatherapy on labor pain and anxiety: The Bitter orange or Citrus aurantium is a member of Rutaceae family (53). Namazi et al. revealed that inhalation aromatherapy with Citrus aurantium essential oil significantly reduced labor pain and anxiety (28).

The effects of Frankincense essential oil aromatherapy on labor pain and anxiety: Frankincense (Boswellia thurifera) is a member of Burseraceae family (54). Burns et al. showed that frankincense aromatherapy can significantly decrease labor pain and anxiety (12). Kyoung and Haeng showed that aromatherapy massage with the conjunction of several essential oils, like frankincense and lavender, has a positive effect on decreasing labor anxiety, just at $8-10 \mathrm{~cm}$ cervical dilatation during the first labor stage (18).

The effects of Clove aromatherapy on labor pain and anxiety: Clove (Eugenie aromatica) belongs to the family Myrtaceae (55). Ozgoli et al. confirmed the higher efficacy of clove aromatherapy than peppermint aromatherapy in reducing levels of pain and anxiety during labor (41).

The effects of Mandarin Orange essential oil aromatherapy on labor pain and anxiety: Mandarin orange (Citrus reticulata) is one of the citrus species of the Rutaceae family (56). In a study by Burns et al, it has been shown that using Mandarin essential oil in combination with four other essential oils (Clary sage, Roman chamomile, lavender, frankincense,) significantly decrease labor pain and anxiety (12).

Summary of the basic features of included studies is presented in Table 1 .

\section{DISCUSSION}

The aim of this systematic review study was to review the effects of aromatherapy on anxiety and pain during labor. We analyzed 33 trials most of which were conducted in Iran. The essential oils used in the included studies were geranium, frankincense, lavender, rose, chamomile, bitter orange, jasmine, sweet orange, mandarin, peppermint, and clove. Most of studies administered aromatherapy through inhalation and then massage. No significant aromatherapy-related side effects were reported in the included studies.

Aromatherapy may be a complementary therapy in decreasing pain and anxiety in labor. In an observational study carried out in a general maternity unit in the UK involving a group of 8053 participants; the use of aromatherapy in labor was investigated. Regardless of maternal group or type of labor induction (spontaneous versus induced), women consistently identified aromatherapy as a valuable complement to their labor experience, and the aromatherapy group had a lower epidural level and opioid injection rate (57-58). Generally, aromatherapy can reduce contraction during delivery, alter functional delivery disorder and reduce delivery time (59).

It has been currently reported that aromatherapy has a positive effect on postpartum physiological and psychological health including depression, fatigue, sleep quality, pain after cesarean-delivery and post-episiotomy pain (60). Also, the relative efficiency of aromatherapy, especially using lavender, in reducing dysmenorrhea has been indicated (61). In a systematic review, it was shown that aromatherapy is more efficient in reducing acute pain than chronic pain (62). Additionally, the favorable, but not conclusive, effects of inhalation aromatherapy on stress management in healthy adults has been proven (63). Lee et al., in a systematic review, indicated the positive anxiolytic effects of aromatherapy in people with anxiety symptoms (64).

The most popular essential oil in the studies was lavender, either as a single essential oil or in combination with other essential oils. In general, our study found that aromatherapy has a positive effect on pain relief and lowers labor anxiety. Only 4 studies suggested that aromatherapy had no

DOI: http://dx.doi.org/10.4314/ejhs.v30i3.16 
significant effect on labor pain and anxiety $(11,12,18,24)$. Small sample size, short duration of intervention and follow-up were the possible explanations for inconsistent results.

Although no serious aromatherapy related sideeffects during labor have been reported in our included studies, a careful attention should be paid by healthcare providers to potential adverse effects such as dermatitis (65).

\section{REFERENCES}

1. Gholipour Baradari A, Firouzian A, Hasanzadeh Kiabi F, Emami Zeydi A, Khademloo M, Nazari $Z$, et al. Bolus administration of intravenous lidocaine reduces pain after an elective caesarean section: Findings from a randomised, doubleblind, placebo-controlled trial. J Obstet Gynaecol. 2017; 37(5):566-570.

2. Lang AJ, Sorrell JT, Rodgers CS, Lebeck MM. Anxiety sensitivity as a predictor of labor pain. Eur J Pain. 2006; 10(3):263-70.

3. Lowe NK, Corwin EJ. Proposed biological linkages between obesity, stress, and inefficient uterine contractility during labor in humans. Med Hypotheses. 2011; 76(5):755.

4. Simkin P, Bolding A. Update on nonpharmacologic approaches to relieve labor pain and prevent suffering. J Midwifery Womens Health. 2004; 49(6):489-504.

5. Jones L, Othman M, Dowswell T, Alfirevic Z, Gates S, Newburn M, et al. Pain management for women in labour: an overview of systematic reviews. Cochrane Database Syst Rev. 2012; (3):CD009234

6. Cooke B, Ernst E. Aromatherapy: a systematic review. Br J Gen Pract. 2000; 50(455):493-6.

7. Tillett J, Ames D. The uses of aromatherapy in women's health. J Perinat Neonatal Nurs. 2010; 24(3):238-45.

8. Hall HG, Griffiths DL, McKenna LG. The use of complementary and alternative medicine by pregnant women: a literature review. Midwifery. 2011; 27(6):817-24.

9. Kheirkhah M, Setayesh Valipour N, Neisani L, Haghani H. A controlled trial of the effect of aromatherapy on birth outcomes using "Rose essential oil" inhalation and foot bath. Journal of Midwifery and Reproductive Health. 2014;2(1): 77-82.

10. Higgins JP, Altman DG, Gøtzsche PC, Jüni P, Moher D, Oxman AD, et al. The Cochrane Collaboration's tool for assessing risk of bias in randomised trials. $B M J .2011 ; 343: \mathrm{d} 5928$.
11. Hur MH, Park MH. Effect of Aromatherapy on Labor Process, Labor Pain, Labor Stress Response and Neonatal Status of Primipara; Randomized Clinical Trial. Obstet Gynecol Sci. 2003; 46(4):776-83.

12. Burns E, Zobbi V, Panzeri D, Oskrochi R, Regalia A. Aromatherapy in childbirth: a pilot randomised controlled trial. BJOG. 2007; 114(7):838-44.

13. Safarzadeh A, Khodakarami N, Fathizadeh N, Safdari F. The effect of massage therapy on the severity of labor in primiparous women. Journal of Shahrekord Uuniversity of Medical Sciences. 2008; 9 (4): 20-25.

14. Mirzaei F, Keshtgar S, Kaviani M, Rajaeifard A. The effect of lavender essence smelling during labor on cortisol and serotonin plasma levels and anxiety reduction in nulliparous women. Journal of Kerman University of Medical Sciences. 2009; 16(3): 245-254.

15. Alavi N, Nemati M, Kaviani M, Tabaie M. The effect of lavender aaromatherapy on the pain intensity perception and intarapartum outcomes in primipare. Armaghane danesh. 2010; 15(1):30-7.

16. Tafazoli M, Zaremobini F, Mokhber N, Emami A. The effects of lavender oil inhalation on level of anxiety during first stage of labor in primigravida women. Journal of Fundamentals of Mental Health. 2011; 12(4): 720-726.

17. Mohammadkhani Shahri L, Abbaspoor Z, Aghel N, Mohammadkhani Shahri H. Effect of massage aromatherapy with lavender oil on pain intensity of active phase of labor in nulliparous women. $J$ Med Plants. 2012; 2(42):167-76.

18. Kyoung LM, Haeng HM. Effects of the Spouse's Aromatherapy Massage on Labor Pain, Anxiety and Childbirth Satisfaction for Laboring Women. Korean J Women Health Nurs. 2011; 17(3): 195.

19. Seraji A, Vakilian K. The comparison between the effects of aromatherapy with lavender and reathing techniques on the reduction of labor pain. Complementary Medicine Journal. 2011; 1(1):34.

20. Vakilian K, Karamat A, Mousavi A, Shariati M, Ajami E, Atarha M. The effect of Lavender essence via inhalation method on labor pain. Journal of Shahrekord University of Medical Sciences. 2012; 14(1): 34-40.

21. Setayeshvali pour N, Kheirkhah M, Neisani L, Haghani H. Comparison of the effects of aromatherapy with essential oils of damask rose and hot footbath on the first stage of labor anxiety in Nulliparous women. Complementary Medicine Journal. 2012; 2 (2): 126-134.

22. Kheirkhah M, Pour NSV, Nisani L, Haghani H. Comparing the effects of aromatherapy with rose

DOI: http://dx.doi.org/10.4314/ejhs.v30i3.16 
oils and warm foot bath on anxiety in the first stage of labor in nulliparous women. Iran Red Crescent Med J. 2014; 16(9):e14455.

23. Ahmadi A, Karimi S, Javadi A. The effect of lavender essence on labor pain in nulliparous women referred to kuosar hospital 2010. Edrak J. 2013; 32: 10-18.

24. Rashidi Fakari F, Tabatabaee Chehr M, Rashidi Fakari F, Mortazavi H, Kamali H, Tayebi V. The effects of aromatherapy on pain of labor in nulliparous women. $J$ North Khorasan Univ Med Sci. 2013; 5(2):359-62.

25. Joseph RM, Fernandes P. Effectiveness of jasmine oil massage on reduction of labor pain among primigravida mothers. Nitte University Journal of Health Science. 2013; 3(4):104-107.

26. Ozgoli G, Aryamanesh Z, Mojab F, Alavi Majd H. A study of inhalation of peppermint aroma on the pain and anxiety of the first stage of labor in nulliparous women: a randomized clinical trial. Qom University of Medical Sciences Journal. 2013; 7(3):21-7.

27. Hamdamian S, Ojab F, Hajian S, Talebi. Investigation of efficacy of rosa amascene aroma on intensity of pain and anxiety in first stage of labor on primiparous in Jajarm javadolame hospital in 2013. [Master Thesis]. Tehran, Iran: Faculty of Nursing and Midwifery of Shahid Beheshti University of Medical Sciences; 2014. (Persian).

28. Namazi M, Akbari SAA, Mojab F, Talebi A, Majd HA, Jannesari S. Aromatherapy with citrus aurantium oil and anxiety during the first stage of labor. Iran Red Crescent Med J. 2014; 16(6):e18371.

29. Heidarifard S, Fallah S, Akbari SAA, Mojab F. Evaluation of the effects of Matricaria chamomilla aroma on intensity of the labor pain in primparous women in Emdadi Hospital of Abhar in 2013. International Pharmacy Acta.1 (1): 99-100.

30. Kaviani M, Maghbool S, Azima S, Tabaei MH. Comparison of the effect of aromatherapy with Jasminum officinale and Salvia officinale on pain severity and labor outcome in nulliparous women. Iran J Nurs Midwifery Res. 2014; 19(6):666-72.

31. Janula R, Mahipal S. Effectiveness of aromatherapy and biofeedback in promotion of labour outcome during childbirth among primigravidas. Health Science Journal. 2015; 9(1):9.

32. Heidaryfard S, Amir Ali Akbari S, Mojab F, Shakeri N. Effect of Matricaria Camomilla Aroma on Severity of first stage Labor Pain. J Clin Nurs Midwife. 2015; 4(3): 23-31.

33. Rashidi Fakari F, Tabatabaeichehr M, Kamali H, Rashidi Fakari F, Naseri M. Effect of Inhalation of Aroma of Geranium Essence on Anxiety and Physiological Parameters during First Stage of Labor in Nulliparous Women: a Randomized Clinical Trial. J Caring Sci. 2015; 4(2):135-41.

34. Rashidi Fakari F, Tabatabaeichehr M. Comparing the effect of geranium and orange essential oils on level of anxiety during delivery. $J$ Mazandaran Univ Med Sci. 2015; 25(123):208-211.

35. Rashidi-Fakari F, Tabatabaeichehr M, Mortazavi $H$. The effect of aromatherapy by essential oil of orange on anxiety during labor: A randomized clinical trial. Iran J Nurs Midwifery Res. 2015; 20(6):661-4.

36. Yazdkhasti M, Pirak A. The effect of aromatherapy with lavender essence on severity of labor pain and duration of labor in primiparous women. Complement Ther Clin Pract. 2016; 25:81-86.

37. Lamadah SM, Nomani I. The effect of aromatherapy massage using lavender oil on the level of pain and anxiety during labour among primigravida women. Am J Nurs Sci. 2016; 5(2):37-44

38. Vahaby S, Abedi P, Afshari P, Haghighizadeh M, Zargani A. Effect of aromatherapy with rose water on pain severity of labor in nulliparous women: a random clinical trial study. Journal of Rafsanjan University of Medical Sciences. 2016; 14(12):1049-60.

39. Roozbahani N, Attarha M, Akbari Torkestani N, Amiri Farahani L, Heidari T. The effect of rose water aromatherapy on reducing labor pain in primiparous women. Complementary Medicine Journal. 2015; 5(1):1042-53.

40. Esmaelzadeh SS, Torkashvand S, Rahimzadeh KM, Lotfi R, Akbari KM, Khosravi N. Effect of aromatherapy with Boswellia Carteri on anxiety in first stage of labor in nulliparous women. Complementary Medicine Journal. 2016; 5(4): 1314-1323.

41. Ozgoli G, Torkashvand S, Salehi Moghaddam F, Borumandnia N, Mojab F, Minooee S. Comparison of peppermint and clove essential oil aroma on pain intensity and anxiety at first stage of labor. Iranian Journal of Obstetrics, Gynecology and Infertility. 2016; 19(21):1-11.

42. Alavi A, Askari M, Nejad ED, Bagheri P. Study the effect of massage with jasmine oil in comparison to aromatherapy with jasmine oil on

DOI: http://dx.doi.org/10.4314/ejhs.v30i3.16 
childbirth process in hospitals of Abadan city in 2013. Ann Trop Med Public Health. 2017; 10:9049.

43. Nehbandanii Z, Rezayee Kahkha Galeh M, Bordbari M, Koochakzai M. Comparison the effects of aromatherapy with rose extract and lavender on the pain of the active phase of labor in primipara women. Scientific Journal of Kurdistan University of Medical Sciences. 2018; 23(5):4554.

44. Cavanagh $\mathrm{H}$, Wilkinson J. Biological activities of lavender essential oil. Phytother Res. 2002; 16(4):301-8.

45. Boukhatem MN, Kameli A, Ferhat MA, Saidi F, Mekarnia M. Rose geranium essential oil as a source of new and safe anti-inflammatory drugs. Libyan J Med. 2013; 8:22520.

46. Boskabady MH, Shafei MN, Saberi Z, Amini S. Pharmacological effects of Rosa damascena. Iran J Basic Med Sci. 2011; 14(4):295-307.

47. Arun M, Satish S, Anima P. Phytopharmacological Profile of Jasminum grandiflorum Linn. (Oleaceae). Chin J Integr Med. 2016; 22(4):311-20.

48. Hongratanaworakit T. Stimulating effect of aromatherapy massage with jasmine oil. Nat Prod Commun. 2010; 5(1):157-62.

49. Ennaifer M, Bouzaiene T, Chouaibi M, Hamdi M. Pelargonium graveolens Aqueous Decoction: A New Water-Soluble Polysaccharide and Antioxidant-Rich Extract. Biomed Res Int. 2018; 2018:2691513.

50. Singh O, Khanam Z, Misra N, Srivastava MK. Chamomile (Matricaria chamomilla L.): An overview. Pharmacogn Rev. 2011; 5(9):82-95.

51. Balakrishnan A. Therapeutic uses of peppermint-a review. J Pharm Sci \& Res. 2015; 7(7):474.

52. Etebu E, Nwauzoma A. A review on sweet orange (Citrus sinensis L Osbeck): health, diseases and management. Am J Res Commun. 2014; 2(2):3370 .

53. Costa CA, Cury TC, Cassettari BO, Takahira RK, Flório JC, Costa M. Citrus aurantium L. essential oil exhibits anxiolytic-like activity mediated by 5 HT 1A-receptors and reduces cholesterol after repeated oral treatment. BMC Complement Altern Med. 2013; 13:42.

54. Al-Yasiry AR, Kiczorowska B. Frankincense-therapeutic properties. Postepy Hig Med Dosw (Online). 2016; 70:380-91.
55. Han X, Parker TL. Anti-inflammatory activity of clove (Eugenia caryophyllata) essential oil in human dermal fibroblasts. Pharm Biol. 2017; 55(1):1619-1622.

56. Viuda-Martos M, Ruiz-Navajas Y, FernándezLópez J, Pérez-Álvarez J. Antifungal activity of lemon (Citrus lemon L.), mandarin (Citrus reticulata L.), grapefruit (Citrus paradisi L.) and orange (Citrus sinensis L.) essential oils. Food Control. 2008; 19(12):1130-8.

57. Burns EE, Blamey C, Ersser SJ, Barnetson L, Lloyd AJ. An investigation into the use of aromatherapy in intrapartum midwifery practice. $T$ J Altern Complement Med. 2000; 6(2):141-7.

58. Burns EE, Blamey C, Lloyd AJ. Aromatherapy in childbirth: An effective approach to care. $\mathrm{Br} J$ Midwifery. 2000; 8(10):639-43.

59. Lis-Balchin M, Hart S, Wan Hang Lo B. Jasmine absolute (Jasminum grandiflora L.) and its mode of action on guinea-pig ileum in vitro. Phytother Res. 2002; 16(5):437-9.

60. Tsai SS, Wang HH, Chou FH2. The Effects of Aromatherapy on Postpartum Women: A Systematic Review. J Nurs Res. 2019 Jun 24. doi: 10.1097/jnr.0000000000000331. [Epub ahead of print]

61. Mousavi Kani K, Mirzania Z, Mirhaghjoo F, Mousavi nezhad R, Akbarzadeh S, Jafari M. The Effect of Aromatherapy (with Lavender) on Dysmenorrhea: A Systematic Review and MetaAnalysis. Int J Pediatr. 2019; 7(7):9657-66.

62. Lakhan SE, Sheafer H, Tepper D. The Effectiveness of Aromatherapy in Reducing Pain: A Systematic Review and Meta-Analysis. Pain Res Treat. 2016; 2016:8158693.

63. Hur MH, Song JA, Lee J, Lee MS. Aromatherapy for stress reduction in healthy adults: a systematic review and meta-analysis of randomized clinical trials. Maturitas. 2014; 79(4):362-9.

64. Lee YL, Wu Y, Tsang HW, Leung AY, Cheung WM. A systematic review on the anxiolytic effects of aromatherapy in people with anxiety symptoms. J Altern Complement Med. 2011; 17(2):101-8.

65. Posadzki P, Alotaibi A, Ernst E. Adverse effects of aromatherapy: a systematic review of case reports and case series. Int J Risk Saf Med. 2012; 24(3):147-61. 